\title{
Allotment gardening in Poland - new practices and changes in recreational space
}

\begin{abstract}
Allotment gardening in Europe, including in Poland, is a century-long tradition that has been cultivated by each new generation. The idea derived from the rapid industrialization of large cities and is currently gaining new meaning. Apart from the economic and recreational roles played by allotment gardens (AGs), emphasis is increasingly being placed on their function as community, social, ecological and even creative and entertainment spaces. AGs constitute an important place for inhabitants of cities to spend their free time. Hence, it has been postulated more and more often that AGs should be preserved as productive and 'living' spaces for leisure and social integration. The numerous initiatives of the Polish Allotment Association, whose aim is to protect AGs against liquidation, and to be used for public and non-public purposes, include the Open Social Programme of Allotment Gardens Development. Through prosocial, innovative activity, the programme helps to redefine and change the perception of AGs in Poland as well as contribute to their infrastructural development.
\end{abstract}

\section{Keywords}

Urban recreational space - Allotment Gardens (AG) • Polish Allotment Association (PAA) - Open Social Programme of Allotment Gardens Development

() University of Warsaw - Faculty of Geography and Regional Studies
Justyna Mokras-Grabowska $\mathbb{C}$

Institute of Urban Geography, Tourism and Geoinformation, Faculty of Geographical Sciences, University of Łódz, Poland e-mail: justyna.grabowska@geo.uni.lodz.pl

\section{Introduction}

For over 200 years, the tradition of allotment gardens $(A G)^{1}$ has been rooted in the European urban cultural landscape. Currently, in Europe, we are observing a growing interest in AGs as an alternative lifestyle option (Crouch \& Ward 1999). In Poland, it has also been postulated that AG, as part of the green recreational urban areas, should be recreational spaces for individual plot users and local communities (Dymek \& Bednorz 2017). Allotment gardening in Poland, administered by the Polish Allotment Association (PAA), takes place in 4,667 allotment gardens encompassing 917,445 plots and covering a total of over 40,000 hectares. $^{2}$ The current problem of AG being liquidated is related to the implementation of new spatial development plans, according to which allotment complexes may be liquidated for public purposes or housing development. Following global trends, however, allotment gardens should be retained as productive and 'living' spaces; they should remain important places for leisure and social integration. Constituting a crucial element of urban green areas, allotment gardens have always been significant recreational spaces for city dwellers, where various free-time activities can be held. Recreational space is understood as a part of geographical space, which has favourable features for recreational processes (Drzewiecki 1992). At the same time, according to the PAA, they should be adapted to facilitate new functions and be opened up to local communities. In order to emphasize the significant role of allotment gardens, the Polish Allotment Association is implementing programmes to modernize

${ }^{1}$ Rodzinne Ogrody Działkowe (ROD) [Allotment Gardens (AG)]

${ }^{2}$ Data obtained from Polish Allotment Association as at 31 December 2018 and improve their condition, as well as make them accessible to local communities. The programmes promote innovative, pro-social activities, in order to involve local communities in cocreating the AG space.

The aim of this article is to answer the research question - how are allotment gardens changing in Poland, mainly due to implementing innovative, pro-social and educational programmes by the Polish Allotment Association, whose aim is to preserve allotment gardens for future generations. The objects of the analysis are the changes in the functions and the significance of $A G$ areas (including on world trends), particularly in the urban recreational space. An important part of the article is the presentation of the practices undertaken within the framework of the Open Social Programme of Allotment Gardens Development, and their benefits. The methodology applied includes a literature review (mainly referring to the history and transformation of allotment gardening in Poland and abroad), analysis of statistical data obtained from the Polish Allotment Association (in particular the changes in number of allotment gardens in Poland due to implemented liquidations) and analysis of the Open Social Programme of Allotment Gardens Development (selected examples). The concluding remarks underline the importance of such practices for the future existence of the gardens.

The history and current situation of allotment gardens in Poland

Allotment gardening is a type of urban gardening, and the most significant component of urban agriculture from the perspective of individual practitioners (Drescher et al. 2006). Rooted in the 
European urban landscape, it has also always been a significant element of the cities' recreational space, understood as leisure space promoting outdoor meeting places. We must also mention its fundamental economic significance (having a place to relax without the need to travel), social function (the intergenerational integration of plot users), as well as the possibility of being selfsufficient (growing one's own vegetables and fruit).

The history of urban gardening dates back to the 17 th century movement of diggers - a farming community condemning social inequality. Contemporary urban gardening started in the 1970s (USA). It combines several phenomena: allotment gardening, community gardening, land sharing (back garden sharing), as well as illegal, informal initiatives, popularly called Guerrilla Gardening (Burgin 2018; Eidimtiene et al. 2016; Fritsche et al. 2011; Drescher et al. 2006). In Poland, a form which is becoming increasingly popular, besides allotment gardening, is community gardening - the community gardens in cities make use of urban fallow land and neglected or degraded areas. Tended collectively, they combine gardening with social participation and environmental education. They activate local communities, strengthen relationships and increase the sense of responsibility for one's neighbourhood.

The idea of allotment gardens was conceived in the 19th century, during times of rapid industrialization in European countries (Szkup \& Pytel 2016; Dymek \& Bednorz 2017). With the Industrial Revolution, allotment gardening concepts emerged, providing opportunities for city dwellers to produce food themselves (Vejre et al. 2016). Although the oldest allotment garden in Poland is officially 'Kappiele Słoneczne' (Sunbaths) in Grudziądz (1897), the idea actually originated in the 16th century, when plots of land were let, under perpetual usufruct, as gardens to city inhabitants (eds Szczurek \& Zych 2012). The first place of this kind in Poland was the Wielkopolska Insurgents Family Allotment Garden in Koźmin Wielkopolski. It was created in 1575, when the Koźmin townspeople were granted fields called 'Błonie' (The Commons) (eds Szczurek \& Zych 2012). The garden still exists today and is considered to be the oldest vegetable and fruit urban garden (a so-called burgher garden). Though it is difficult to say for certain whether former burgher gardens could evolve into the contemporary AGs, they are often regarded as the precursor of organized allotment gardening in Poland.

A later form of allotment gardening appeared on Polish land in the second half of the 19th century. It came mostly from Germany and was a way of helping the poorest townspeople. The creation of allotment areas was powered by rapid industrialization at the end of the 19th century and the socio-economic problems that appeared in cities as a result. The growing population and, at the same time, the worsening hygienic conditions in cities caused widespread social protest, which highlighted the necessity to create garden areas (Duś 2011). They developed most rapidly in Silesia, Wielkopolska, Pomerania and Warsaw (Wolaniuk 1991). Allotment gardens were an indispensable amenity in the housing estates inhabited by miners and other workers in Silesia. ${ }^{3}$ They were also a form of allowance for the unemployed and the poorest, providing basic food products (fruit and vegetables). However, the first allotment garden created in the 19th century 'Kąpiele Słoneczne' in Grudziądz, was the initiative of Doctor Jan Jalkowski, the founder of the Natural Way of Life Association. It should be highlighted that the aims of the garden were strongly recreational - it served the inhabitants of Grudziądz as a place to do outdoor exercise, have peat mud baths and sunbathe (Jak powstawały ogrody działkowe? 2011).

Allotment gardens developed on a large scale after World War I (Szkup \& Pytel 2016). In 1918, after Poland regained independence, there were 19 gardens in the country, covering

${ }^{3}$ The oldest gardens were those established in 1905 (still functioning): A. Czarnecki AG in Chorzów and AG 'Hope' ('Nadzieja') in Toszek (eds Szczurek \& Zych 2012). about 70 hectares and consociating over 2,000 plot users (Pawlikowska-Piechotka 2009). It was during the interwar period that holidays for children living in the city were organized in allotment gardens, and in 1933 when the 'Działkowiec Śląski' (The Silesian Plot User) monthly magazine appeared. Before the outbreak of World War II, there were already 606 allotment gardens with nearly 50,000 users in Poland.

Allotment gardening flourished during the socialist period. World War II and the need to improve the living conditions in the hard, post-war years stirred a rapidly growing interest in allotment gardens all over Europe (Pawlikowska-Piechotka 2009). The idea of allotment gardening perfectly fitted with the aims of a socialist country. Allotment gardening became an essential feature of Polish middle-class households continuing the workingclass tradition. They performed significant social functions as well, enabling city inhabitants to have a place to relax for a low price. During and immediately after the war, working on plots also gave the inhabitants of European cities a chance to survive. The famous propaganda slogan 'Dig for Victory' from the times of World War II encouraged citizens to cultivate every single unoccupied piece of soil (the so-called war gardens or emergency gardens) (Spilková \& Vágner 2016). Gardens were praised for their productive function and were a kind of response to food shortages (Barthel et al. 2013). The crisis of the 1930s and the period of World War II contributed to the huge interest that was placed in allotment gardens all over Europe. In Poland, the decree nationalizing land ownership (1946) allowed for the easy creation of new gardens, giving people the opportunity to improve their material existence in the difficult post-war years (PawlikowskaPiechotka 2009). Over time, suggestions called for the so-called open gardens to be created, which would give people living in the vicinity an opportunity and a place to relax (Piątkowska 1983). It was also postulated that allotment gardens should be situated close to home - at a distance of around 15 minutes' walk or ride by public transport. An interesting solution to the problem of how to assign the allotments to a maximum number of families was to locate the gardens outside the city - the allotments were to be better equipped with recreational amenities, providing conditions for weekend stays (the concept of 'camping allotments' or 'suburban allotments') (Piątkowska 1983). Hence, during the political surveillance under the communist regime allotment gardening flourished. In May 1949, the first legal Act concerning workers' allotment gardens was adopted; the next one in May 1981. Allotment gardens became the property of the State Treasury, and the Polish Allotment Association was set up and obtained the right to the free use of land. Thus, the allotment movement in Poland became independent.

Socio-economic changes after the fall of communism (1989) caused a significant part of the Law Act of 1981 to become outdated. New problems and threats appeared, so that after 1990 the number of allotment gardens declined - they were demolished by developers, built upon for new housing estates or requisitioned and returned to their previous landowners. Allotment gardens were handed over by the State Treasury to local authorities. The new Allotment Gardens Act (8 July 2005) was adopted and was impeached by the Constitutional Court. Finally, the Family Allotment Gardens Act of 13 December 2013 enabled the achievements of the Polish allotment gardening movement to be preserved. To sum up, although the transformation of allotment gardens into permanent residences to meet the needs of transportation infrastructure has diminished since 1989, the previous socio-economic system had certainly left a considerable area of allotment gardens in the functional-spatial structure of large Polish cities (Szkup \& Pytel 2016).

At present, AG in Poland are administered by the Polish Allotment Association, and the owners of the land where 


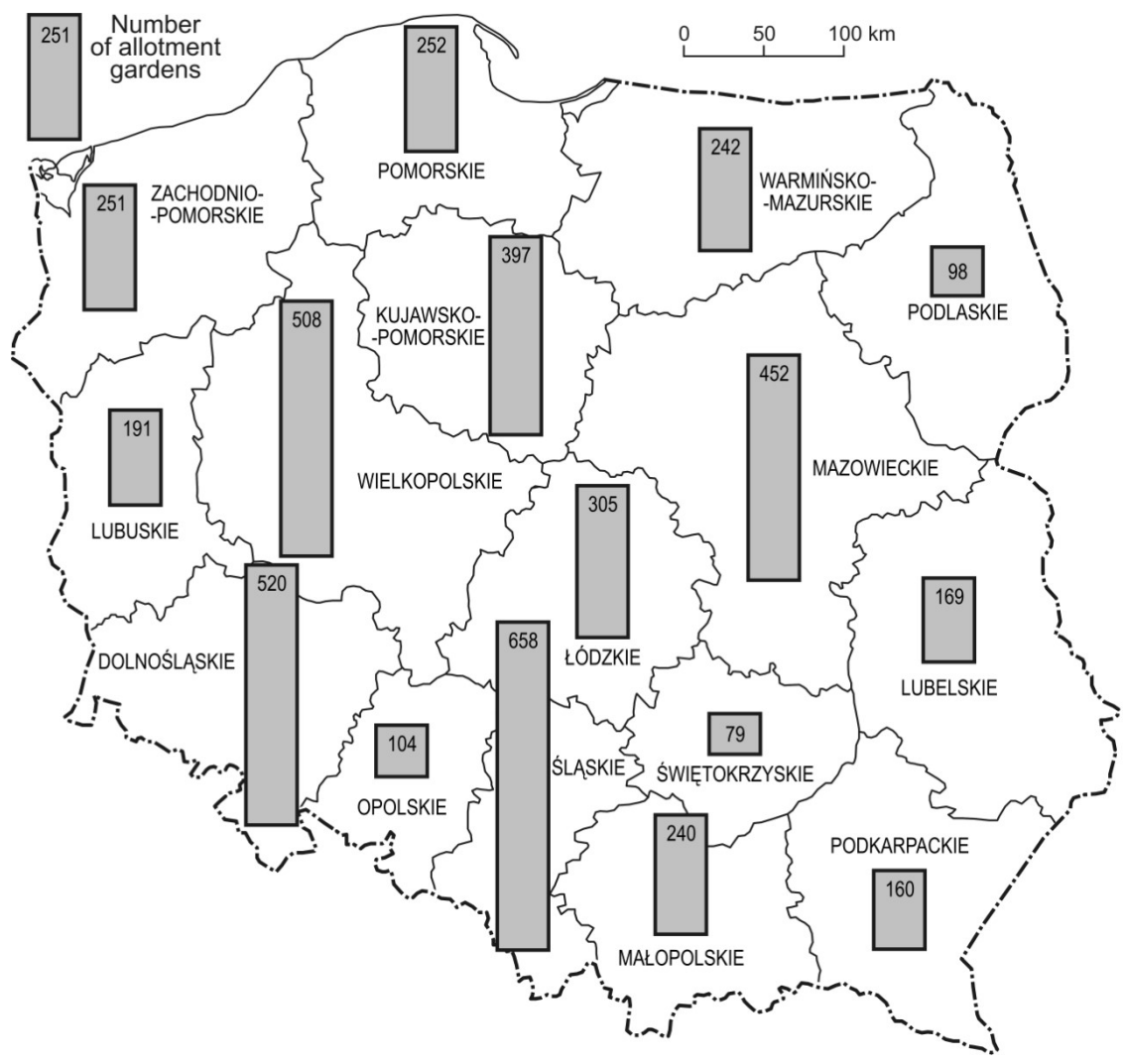

Figure 1. The number and concentration of allotment gardens in Poland by province in 2018 Source: own elaboration based on data obtained from the Polish Allotment Association

allotment gardens are situated are communities and the State Treasury. It is commonly believed that AG should not be closed, made unavailable to other inhabitants or detached from other recreational areas (Duś 2011). Allotment gardening in Poland, administered by the Polish Allotment Association, encompasses 4,667 gardens with 917,445 plots, covering a total of over 40,000 hectares. ${ }^{4}$ As shown in Figure 1 the highest number of allotment gardens is concentrated in Silesia (658), Lower Silesia (520) and Wielkopolska (508) provinces. The same applies to the number of plots (Fig. 2). As mentioned above, the highest number of allotment gardens and plots in Silesia is connected with the rapid industrialization of the region. It can also be seen that some provinces in Poland have a much lower number of gardens and plots (e.g. along the eastern border of the country) due to less economic development and hence, less industrialization.

According to the Allotment Gardens Act of 13 December 2013, ${ }^{5}$ gardens and plots are public utilities, serving the purpose of satisfying the recreational and social needs of local community members. Moreover, they are green areas, protected by laws for the protection of farming and forest areas, and for the preservation of nature and the environment. ${ }^{6}$

The situation of allotment gardens in other countries

In order to better understand the present state of allotment gardening in Poland, it is important to refer also to some European historical trends; therefore, this chapter evokes many foreign issues.

${ }^{4}$ According to PAA data (31.12.2018)

${ }^{5}$ Family Allotment Gardens Act 13.12.2013 (Journal of Laws from 2014, item 40)

${ }^{6}$ Nature Conservation Act 16.04.2004 (Journal of Laws from 2004, no 92, item 880)
Taking the transformations of allotment gardening in other European countries and in North America into consideration, the history of allotment gardens dates back to the late 19th century and is strongly connected with the industrialization of cities (Wolaniuk 1991). Setting up allotment gardens was initiated by charity associations (the plots were allocated to the poorest, according to the slogan: 'Work instead of alms'). Farming practices allowed urbanites to grow much of their own food and avoid mass starvation (Barthel et al. 2013; Vejre et al. 2016). There is no agreement as to the year the first allotment garden in the world was created - some people believe that it happened in Sedan (France) in 1889; others, in Leipzig (Germany), in 1864. However, it is usually the German case that is considered in the literature on the subject as the first workers' garden in Europe (Wolaniuk 1991). Similar gardens were later created in Belgium, France, Germany, England and the USA.

In the USA, the history of community gardening dates back to the early 18th century (North Carolina). In March 1917, the US National War Garden Commission was launched, mainly due to poor supplies of food (victory gardens). Nowadays community gardens in the USA are important gathering places and showcases for art and ecological awareness. There are also some gardens resembling European allotment gardens, where plots differ in size. The primary advocacy group for community gardening in the USA (and Canada) is the American Community Gardening Association (ACGA) (Bassett, 1981).

The beginnings of allotment gardening in Germany should be sought in the activity of Doctor Ernst Innocenz Hauschild, who set up the first Schrebergarten in 1865, in Leipzig (Nakonieczny 2018). Doctor Hauschild chose the name to honour his friend, Daniel Schreber, who propagated the idea of a healthy lifestyle 


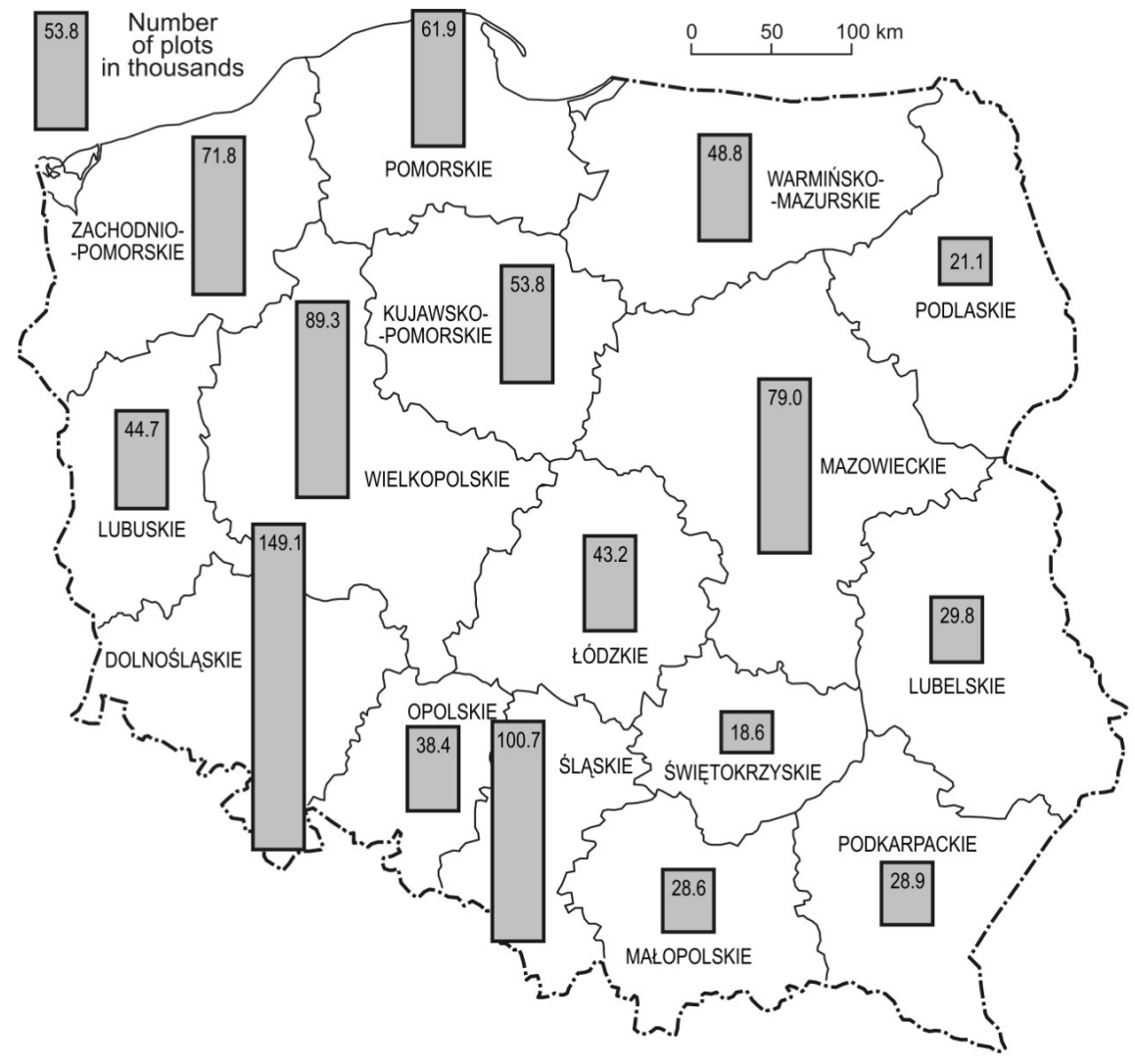

Figure 2. The number of plots belonging to allotment gardens in Poland by province in 2018 Source: own elaboration based on data obtained from the Polish Allotment Association

among children and youth living in industrial cities, the number of which was growing due to rapid and uncontrolled urbanization in the 19th century. Initially, the Schrebergarten was used mainly for sport and recreation, and the marginal gardening activity had rather an educational purpose. With time, the allotments changed into cultivable plots, always including small playgrounds for children. In 1870, the first 'colony' of small houses with gardens for workers was created on the outskirts of Berlin (eds Szczurek \& Zych 2012). Combining these two ideas, allotment gardens appeared in Germany at the end of the 19th century and from this time the number of allotment gardens rose from a few hundred to 800,000 at the end of World War II (Barthel et al. 2013).

It is worth mentioning that in some European countries, such as Sweden and Switzerland, allotment gardens were created to promote family values. In Great Britain, in turn, it gradually became clear that it was necessary to isolate places in the city to support badly paid workers eds (Szczurek \& Zych 2012). In England alone, 440,000 plots had already been cultivated by 1890 , both in urban and suburban areas. It should be mentioned that earlier in England, there were also the so-called Guinea Gardens - decorative gardens for the urban middle class (artisans, shopkeepers, office workers).

Nowadays, in many countries all over the world, buying ownership rights to a plot of land is increasingly popular. According to Acton (2011), the national waiting list had reached 95,000 (increase of 17,000 from 2009) in England in 2010. Ownership differs in various countries - the gardens are not privately owned; the land belongs to the state, religious organizations or associations; or the users lease the allotments. The different forms of urban gardening in the USA and European countries, including allotment gardening, are currently perceived as a type of social innovation, satisfying the basic nutritional needs (own crops), as well as the need for social intergenerational integration (Eidimtiene et al. 2016). In Germany, there are almost a million allotment gardens (most of them in Berlin - over 69,000), used by nearly five million plot users. The situation is similar in Great Britain, where the possibility of sustainable plant cultivation is emphasized. In Denmark, the government, which supports the idea of allotment gardening, initiates the creation of many new gardens. In Sweden, allotment gardens are an important part of the cultural heritage, thus a significant element of the everyday life of the inhabitants. In the USA, despite the fact that community gardening is much more popular, new allotment gardens are constantly being created. In many countries, they are islands of peace and quiet, though still encouraging social contact, the exchange of experiences and an active social life. Allotment gardens are places where a variety of recreational activities take place and aim to improve the integration and recreation of people with special needs (the disabled, or socially excluded). In this way, urban gardening is becoming a form of therapy. However, it should be highlighted that allotment gardens are also under threat in many cities across the world due to the pressure from residential and infrastructure development (in the UK, Spain and the Netherlands, among others) (Spilková \& Vágner 2016).

The transformations of the functions and significance of allotment gardens

The situation of allotment gardens is gradually changing. After 2000, there was a new wave of interest in allotments as an opportunity to adopt an alternative lifestyle, as well as to support 
the household budget (eds Szczurek \& Zych 2012). It is common for inhabitants of European capitals to wait several years to be allocated plots of land. In well-off districts, allotments still function, even though their users can easily afford other forms of leisure. A new understanding of allotment space is emerging; allotments are increasingly opening to local communities; they are a segment of integrated urban space (Dymek \& Bednorz 2017). They enable the multifunctional use of urban land, such as providing an open space for community and family activities (social cohesion) (Spilková \& Vágner 2016). Recreation and health needs (the need to rest, relax and have fun) are becoming the most common reason why people want to own a plot. It should be highlighted, however, that work is still the essence of allotment gardens. An allotment is a place where leisure is interwoven with work time.

In Poland, the demand for allotments is also systematically growing. Every year, garden plots are allotted to about 50,000 families (Programy PZD 2019). There is also a new category of plot users who seek tranquillity and rest in their gardens, not necessarily to plant fruit and vegetables. The survey conducted by the National Council of the Polish Allotment Association in cooperation with the local PAA and AG administrations in 2011 showed that $21.21 \%$ of the $A G$ included in the study were purely recreational plots, $20.07 \%$ of the respondents used their plots for growing plants, and nearly $60 \%$ were plots combining recreation and cultivation. ${ }^{7}$ Fruit and vegetable crops are slowly disappearing from allotment gardens (Kim są polscy działkowcy? 2011).

Hence, over the years or even centuries, the functions of allotment gardens (in Poland also) have been undergoing considerable transformations. Currently, apart from some purely economic functions (temporary accommodation, food), allotment gardens play many other roles: recreational (recreational space), integrative, communal (space for human interactions between generations), economic (the possibility of cheap recreation with no need to travel from the permanent living area and its vicinity, a kind of substitute form of leisure when possibilities of travelling are limited), promoting family values, animating local communities, hygienic, therapeutic, socio-educational (enriching the sphere of cognition), ecological (building ecological awareness in city inhabitants, biodynamic and permaculture, green belts, living according to the philosophy of Slow Food, Slow Life), creative (users shaping the space), while improving urban quality of life and maintaining a balance between people and nature (Spilková \& Vágner 2016; Duś 2011; Gawryszewska \& Myszka-Stapór 2016; Eidimtiene et al. 2016; Lovell et al. 2014; Fritsche et al. 2011; Poniży \& Stachura 2017; Pawlikowska-Piechotka 2009). Moreover, allotments are a kind of refuge, especially for elderly people who feel they possess a piece of (rented) land - a place where they feel 'at home' and truly free; it can be a way of dealing with old age. Allotments are a kind of 'third space', characterized by many dichotomies: they are private and public spaces, for production and consumption, for both work and leisure (Spilková \& Vágner 2016). It must be highlighted, however, that the main idea behind allotment gardens is the preservation of the gardening function connected with growing your own fruit and vegetables.

Allotment gardens in Poland, once situated on city peripheries, are currently to be found in central districts due to dynamic urbanization (Pawlikowska-Piechotka 2009). According to the research conducted by M. Szczurek and M. Zych (eds 2012) there is a common belief that allotments do not match the iconic representations of a modern city, such as shopping centres, densely built-up areas, guarded housing estates and office buildings. Allotments, with their disorderly buildings and controversial aesthetics, are an element of disharmony in the contemporary, dynamically changing cityscapes and their

\footnotetext{
${ }^{7}$ The survey was conducted in almost half of the AGs in Poland (48.22\%) (Kim są polscy działkowcy? 2011)
}

designer visions. After political transformations, neglected (or even abandoned, or demolished) landscapes of many allotment gardens located within the city centre can be observed. There is the belief that allotment gardens spoil the landscape and view, wiping out the sublime, picturesque qualities. They don't look like typical gardens because of their chaotic and unconventional infrastructure.

The appearance and development of allotments in Poland is changing, though. Vegetable patches and fruit trees are being replaced with new types of planting - decorative shrubs, exotic flowers or simply vast lawns, used as recreational gardens.

Garden arbours are often built by professional construction companies nowadays, turning them into stylish places to rest. There are so-called hungry plots as well, where no crops are grown, and which are used exclusively for recreation. On the other hand, ecological gardening (growing experimental plants as a hobby), in line with healthy lifestyle trends, is becoming very fashionable in Poland.

\section{Liquidation of allotment gardens in Poland}

Favourable location, municipal utilities and good transport infrastructure made allotment gardens in large Polish cities attractive areas for construction development. The downside is that allotment gardens often face the threat of being taken over by developers (Pawlikowska-Piechotka 2009; Poniży \& Stachura 2017). Continuous urban development means that new areas are sought for investing in developing housing construction. The growing Polish metropolises are 'engulfing' allotment gardens. Saving them depends on regulating their legal status. They are a significant element of spatial development plans or spatial development conditions and directions studies. Classifying an area as other than an allotment may mean liquidating the $A G$ in the future, for a public or non-public purpose. The data provided by the PAA shows that over $69 \%$ of the area occupied by allotment gardens in Poland is classified in the development plans as allotment greenery $(623,751$ plots; a $3 \%$ decrease compared to 2016). AG areas that are not subject to either spatial development conditions and directions studies or local spatial development plans constitute $5 \%$ of the total allotment garden area (42,360 plots). The majority of them are located in the Poznań and sub-Carpathian districts. Moreover, proceedings that concern approving or changing plans or development studies are pending, and this affects over $5 \%$ of AG areas in Poland $(52,738$ plots). The most difficult situation is observed in the following districts: Częstochowa, Elbląg, Małopolska, Pomerania and Mazovia. In the Mazovia District alone, urban plans include $40 \%$ of the whole allotment gardens area in Warsaw.

According to the data provided by the PAA, in 2015-2019, there were 312 liquidations (3,277 plots), including 16 allotment gardens liquidated in full (the remaining cases were partial liquidations). As Figure 3 shows, most liquidations took place in 2017, which may be associated with the large number of investments carried out in Poland in general. Those carried out for public purposes (usually due to communication infrastructure development) made up $17 \%$ of all liquidations, and those having a non-public purpose or in connection with other situations, $27 \%$.

The largest number of liquidations concerned the land left behind due to partial $A G$ liquidations for public purposes (56\%). In 2015-2019, liquidations that were started but not completed concerned 253 AGs (3,462 plots). The majority of the liquidations currently in progress $(53 \%)$ are for public purposes.

Open Social Programme of Allotment Gardens Development as an example of pro-social activity

In 2015-2019, in response to the changing situation of allotment gardens in Poland, as well as the growing expectations 


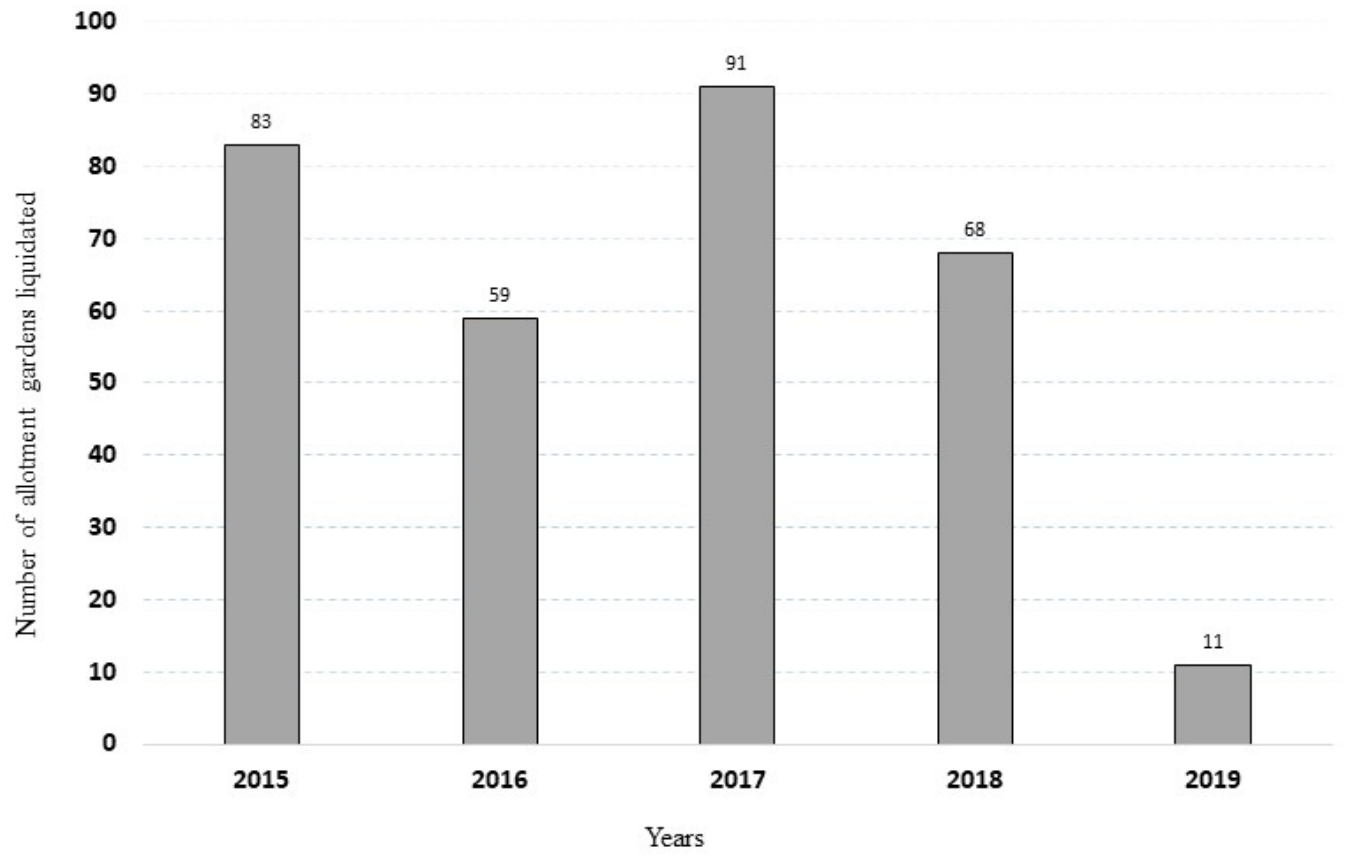

Figure 3. Number of allotment gardens liquidated in Poland in 2015-2019 Source: own elaboration according to data obtained from the PAA

of cities and local communities with regard to the gardens, the PAA National Council implemented several development programmes (Programy PZD 2019). As a result, new AG are being created and the existing ones are being modernized. Moreover, the social significance of allotment gardens and their role in the urban greenery system have been recognized. Another new idea is 'open gardens', whose functional value as recreation areas available to all city dwellers is expected to rise. It is believed that allotment gardens should not be closed units, inaccessible to the remaining inhabitants, or somehow 'detached' from the system of urban recreational areas (Duś 2011). It has been recommended that they should be accessible in a limited way - for instance, through solutions applied in other European countries, such as locating recreational areas and playgrounds for children at their edges. Some attempts to open allotment gardens in Poland to local communities have also been made in the past. The first holiday stays for nearly 100 children were organized in 1925, in Poznań Province (Wolaniuk 1991). Similar holidays for children from miners' families were first organized in Silesia in 1933.

The development programmes currently implemented in Poland include the following: 'AG Infrastructure Modernization Programme - AG in the 21st century', 'AG Development Open Programme', 'Modern Development and Use of Allotments to Match the Needs of Contemporary Families', 'Polish Allotment Association Open Educational Programme' and 'Safe Allotment Gardens Open Programme'.

Particularly important for the preservation of allotment gardens for future generations, and, at the same time, for their redefinition in Poland is the Open Social Programme of Allotment Gardens Development (Programy PZD 2019). It is an answer to the current significant changes in the functions of allotment gardens. The programme responds to the recreational and social needs of the local communities and performs pro-social and educational functions as well. An important objective of this programme is to open the gardens to local communities, which would enable them to participate in the life of allotment gardens. Many activities for different social groups have been initiated, including for the elderly and disabled people who are often marginalized. Local self-governments have also been invited to cooperate. Such activities are slowly raising the attractiveness of allotment gardens in Poland, whose infrastructure is being modernized. They also satisfy the needs of modern societies as freely accessible urban green areas. As a result, according to the PAA, AG will enjoy increasing public support and popularity, which means that their role in the urban greenery system will be appreciated. This, in turn, may save allotment gardens from liquidation and preserve them for future generations. They are not only the green lungs of the city, but also a place where the whole local community can rest, learn, integrate and spend their free time. The activities proposed in the programme are intended to merge the gardens with the city and local communities (Programy PZD 2019).

The new practices promoted in the Open Social Programme of Allotment Gardens Development include innovations, such as ecological education (cooperating with educational institutions, e.g. giving plots over to schools and kindergartens free of charge) and the organization of green schools, cultural and sports events for the disabled, and meetings with cultural and holiday stays for elderly people. They also include creating play zones for children, and outdoor gyms. Moreover, some traditional activities are to be continued and supported, such as integration events for the allotment users, an AG Open Day, a Plot User's Day, AG jubilees, fairs, competitions and picnics for different social groups (including the disabled). As a result of these new practices, allotment gardens have opened up to local communities and become an important part of the urban greenery system. The programme includes cooperation with territorial self-governments in order to organize joint events.

Such activities, however, require providing AG with proper infrastructure. In order for the city inhabitants to use open allotment gardens, it is necessary to make new investments in the form of garden path lighting, public toilets, benches, security, open playgrounds, etc. At the request of the PAA, which is a non- 
governmental organization, public tasks may be commissioned for allotment gardens. Hence, financing these needs is possible not only due to the restricted grants from the AG Development Fund, ${ }^{8}$ but also subsidies from the city and commune budgets, the so-called small grants from the city or district budgets, the civil (participatory) budget, EU funds and ministerial programmes. ${ }^{9}$ It is worth looking closer at some practices included in the programme.

An example from the Sudety District is a plot that was given over to an educational institution (local primary school) -'White Stone' AG in Wałbrzych (Polski Związek Działkowców 2020). The children prepared a development plan, cleaned the plot and planted plants under the supervision of the local gardening instructor, who taught them the basic rules of planting, and explained the anatomy of plants and how they can be used for culinary purposes. Similarly, the T. Kościuszko AG in Łobżenica (Wielkopolska District), gave three plots free of charge to the local primary school. They were turned into an educational site, with a weather station, information boards, benches and teaching aids. With the help of their teachers, children planted trees and shrubs. The necessary means were provided from the Environment and Water Economy Fund in Poznań Province. Similar decisions were taken by the T. Kościuszko AG in Wronki and 'Malwa' AG in Piła (Wielkopolska District).

The administration of the 'Jutrzenka' AG in Radzionków, in cooperation with the Radzionków municipality, decided to create an educational path with thematic boards for the inhabitants of the town, promoting the natural environment of an allotment garden (Gmina Radzionków 2020). The offer was directed primarily at the local educational institutions. The boards are located on the outside of the fence surrounding the garden, so there is no need to enter the premises.

An interesting example of infrastructure modernization in a family allotment garden and adapting it to new functions is the 'Polanka' AG in Łódź, where the Park of Active Rehabilitation was created. The garden, situated in the Łódź Hills Landscape Park, organizes 'eco-meetings' for the elderly within the framework of the Eco-Senior Project, co-financed by the Ministry of Labour and Social Policy (a part of the Government Programme for the Activeness of Elderly People). The topics discussed during the meetings included eco-food, dietetics, ecological crops and the activities of elderly people.

Holidays for the elderly are organized in the 'Rakowiec' AG in Warsaw (Polski Związek Działkowców 2020). According to PAA data, the holidays organized in summer 2015 attracted 60 seniors. The participants were mostly lonely people, who had no possibility of spending their free time away from home. They attended thematic lectures, handicraft workshops, concerts and outdoor games. The event was supported by plot users and proved

\footnotetext{
${ }^{8}$ The subsidy has favourable interest rates, split into instalments spread over a numer of years.

${ }^{9}$ The activities implemented under the programme have so far been financed from the Civic Initiatives Fund and 'Senior-Vigor' Programme, among others.
}

that allotment gardens are a good place for intergenerational integration. Holidays for the elderly are also organized by other allotment gardens in Poland, including 'Koło II' AG in Warsaw, 'Wielkopolska Insurgents' AG in Chocież and 'Gold Sands' AG in Siedlce. Many gardens include outdoor gyms and playgrounds for children, for example the 'Kolejarz' AG in Inowrocław, 'Dębniki' AG in Kraków or 'Leśny' AG in Mała Huta (Podlassia District).

The Open Social Programme of Allotment Gardens Development is a perfect example of the significant role allotment gardens play in the urban greenery system, especially in the recreational space of large cities.

\section{Conclusions}

In the contemporary world, cities are increasingly lacking greenery. Urban sprawl and, consequently, the shrinking areas of urban greenery, pose a serious threat. The current spatial policy of cities is focused on creating new green areas while the areas which could be potentially used by the inhabitants for recreational purposes are taken over by developers. Thus, allotment gardens in Poland are extremely important for the sustainable development of urbanized areas, in relation to an improvement in the living environment, the promotion of healthy lifestyles, accessibility for all age and social groups, as well as high biodiversity. They are often a space used by many generations and, in a way, connecting these generations. They are also an important element of the spatial composition of cities. Despite the pressure exerted by developers and the fact that pollution has a negative impact on the crops, allotment gardens should not be liquidated. The change of their cultural functions, from agricultural-productive to recreational, opens them up to many innovative initiatives, emphasizing the role of allotment gardens in the urban greenery system. According to the concept of sustainable development, cities should provide the means to satisfy inhabitants' needs connected with work and recreation, which ultimately results in a better quality of life in the city. This is what allotment gardens are for - they are symbolic spaces, 'familiar' and friendly. Despite the fact that access to them is still very limited, they create the identity of local communities, playing an enormous role in the city ecosystem. Such ideas are supported by the pro-social activities initiated within the framework of the Open Social Programme of Allotment Gardens Development. The aim of this article was to answer the research question - how are allotment gardens changing in Poland, mainly due to implementing innovative, prosocial and educational programmes implemented by the Polish Allotment Association. In conclusion it should be highlighted that such new practices undoubtedly affect urban recreational space through the development of new recreational infrastructure for city dwellers, implementing pro-social activities and finally saving allotment gardens as useful elements of urban green areas.

\section{ORCID}

Justyna Mokras-Grabowska (D) https://orcid.org/0000-00030994-5484

\section{References}

Acton, L 2011, 'Allotment Gardens: A reflection of History, heritage, community and Self', Papers from the Institute of Archeology, vol. 21, pp. 46-58. DOI: 10.5334/pia.379.

Allotment Gardens Act 13.12.2013 (Journal of Laws from 2014, item 40).

Bassett, T J 1981, 'Reaping on the margins: A century of community gardening in America', Landscape, vol. 25, no 2, pp. 1-8.
Barthel, S, Parker J, Ernstson H 2013, 'Food and green space in cities: A resilience lens on gardens and urban environmental movement' in Urban Studies, New York: Routledge, pp. 1-18, DOI: 10.1177/0042098012472744.

Burgin, S 2018, 'Sustainability as a motive for leisure-time gardening: a view from the 'veggie path", International Journal of Environmental Studies, 75:6, pp. 1000-1010, DOI: 10.1080/00207233.2018.1464277. 
Crouch, D \&Ward, C 1999, The Allotment. ITS Landscape and Culture, Nothingam: Five Lives Publication.

Drescher, A W, Holmer R J, LaQuinta D I 2006, 'Urban homegardens and Allotment Gardens for sustainable livelihoods: Management strategies and institutional environments' in Tropical Homegardens: A time-tested example of sustainable agroforestry, eds. B M Kumar \& P K R Nair, pp. 317-338. Springer.

Drzewiecki, M 1992, Wiejska przestrzeń rekreacyjna ['Rural recreational space'], Instytut Turystyki, Warszawa.

Duś, E 2011, 'Miejsce i rola ogrodów działkowych w przestrzeni miejskiej' ['Meaning of Allotment Gardens in the urban space'], Geographia. Studia et Dissertationes, vol 33 (2011), pp. $79-100$.

Dymek, D \& Bednorz, L 2017, 'Zagospodarowanie Rodzinnych Ogrodów Działkowych (ROD) im. Józefa Chociszewskiego w Poznaniu' ['The development of Allotment Gardens (AG). A case study of Józef Chociszewski FAG in Poznań'], Studia Miejskie, vol. 25 (2017), pp. 133-147, DOI: 10.25167/ sm2017.025.08.

Eidimtiene, VV, Auzeliene I \& Daubaras, L 2016, 'Urban gardening: elements, social, cultural and recreational aspects', MAZOWSZE Studia Regionalne, no 18/2016, pp. 35-47, DOI: 10.21858/msr.18.03.

Fritsche, M, Klamt M, Rosol M, \& Schulz, M 2011, 'Social Dimensions of Urban restructuring: Urban Gardening, Residents'Participation, Gardening Exhibitions' in Perspectives in Urban Ecology, eds. W. Endlicher et al., Springer-Verlag Berlin Heidelberg, Chapter 9, pp. 261-295, DOI: 10.1007/978-3-642-17731-6_9.

Gawryszewska, B \& Myszka-Stąpór, I 2016, 'Ogrody towarzyszące zamieszkiwaniu w procesach rewitalizacji i redefiniowaniu przestrzeni miejskich' ['Gardens accompanying indwelling in city space revitalisation and redefinition processes'], Prace Komisji Krajobrazu Kulturowego [Dissertations of Cultural Landscape Commission], no 32/2016, pp. 71-82.

Gmina Radzionków [Radzionków Commune], 2020. Available from: <http://www.radzionkow.pl. [12.05.2020].

Jak powstawały ogrody działkowe? Prace konkursowe [How were allotment gardens created? Competition works] 2011, KR PZD, Warszawa.

Kim są polscy działkowcy? Badanie wykonane przez Krajową Radę PZD przy współudziale okręgowych zarządów PZD $i$ zarządów ROD ['Who are Polish gardeners? The study carried out by National Council of PAA with the participation of regional boards of PAA and boards of AG'] 2011, KR PZD, Warszawa.

Lovell, R, Husk K, Bethel A, \& Garside, R 2014, 'What are the health and well-being impacts of community gardening for adults and children: a mixed method systematic review protocol', Environmental Evidence 2014, 3:20, pp. 1-13.

Nakonieczny, R 2018, Wielokulturowość Górnego Śląska na przykładzie Ogrodów Szreberowskich i Jordanowskiego w Katowicach ['Multiculturalism of Upper Silesia on the example of Schreber and Jordan gardens in Katowice'], Fundacja Dom Modernisty, Katowice.

Nature Conservation Act 16.04.2004 (Journal of Laws from 2004, no 92 , item 880).

Pawlikowska-Piechotka, A 2009, 'Ogrody działkowe w rozwoju zrównoważonym współczesnego miasta' ['Allotment gardens in sustainable development of the city'] Problemy Ekologii, vol. 13, no 2, 2009, pp. 106-111.

Piątkowska, K 1983, Zieleń $i$ wypoczynek, ['Greenery and leisure'], IKŚ, Warszawa.

Polski Związek Działkowców [Polish Allotment Association], 2020. Available from: <http://www.pzd.pl. [12 May 2020]
Poniży, L \& Stachura, K 2017, 'Future of Allotment Gardens in the context of city spatial policy - a case study of Poznań', Quaestiones Geographicae, vol. 36 (1), pp. 121-127, DOI: 10.1515/quageo-2017-0009.

Programy PZD ['Polish Allotment Association Programs'] 2019, PZD, Warszawa.

Spilková, J \& Vágner, J 2016, 'The loss of land devoted to allotment gardening: the context of the contrasting pressures of urban planning, public and private interests in Prague, Czechia', Land Use Policy, 52, pp. 232-239, DOI:10.1016/j. landusepol.2015.12.031.

Szczurek, M \& Zych, M 2012, 'dzieło-działka', ['plot-work'], ed., Muzeum Etnograficzne im. Seweryna Udzieli w Krakowie Kraków.

Szkup, R \& Pytel, S 2016, 'Rodzinne Ogrody Działkowe (ROD) w przestrzeni dużego miasta. Przykład Łodzi' ['Allotment Gardens in the big city. Case study of Łódź'], Prace Komisjii Krajobrazu Kulturowego [Dissertations of Cultural Landscape Commission], no 32/2016: 109-124, pp. 109124.

Vejre, H, Eiter S, Hernández-Jiménez V, Lohrberg F, LoupaRamos I, Recasens X, Pickard D, Scazzosi L \& Simon-Rojo M 2016, 'Can Agriculture Be Urban?', in Urban Agriculture Europe, eds. F. Lohrberg, L. Lička, L. Scazzosi \& A. Timpe, pp. 18-25, Berlin: Jovis Verlag.

Wolaniuk, A 1991, 'Ogrody Działkowe Łodzi jako teren wypoczynku mieszkańców miasta' ['Gardening plots in Łódź as a recreational area for the city dwellers'], Turyzm vol 1 (1991), pp. 31-53. 